\title{
Analisis Perbandingan Metode Perhitungan Bunga Penjualan Angsuran Pada Honda Cengkareng
}

\author{
Rosdiyati, Sripah Asma Wahyuni \\ Fakultas Ekonomi, Universitas Islam Lamongan \\ Email authors: roeshanif@gmail.com, sripahasma99@gmail.com
}

\begin{abstract}
ABSTRAK
Penjualan angsuran lebih diminati oleh masyarakat, khususnya penjualan atas barang dengan nominal yang tinggi. Tujuan dalam penelitian ini adalah membandingkan metode perhitungan bunga dengan metode sisa harga kontrak, metodelong end interest, metode short end interest, dan metode anuitas. Jenis penelitian adalah penelitian kuantitatif yang digunakan untuk menghitung bunga penjualan angsuran Honda Cengkareng. Hasil penelitian menunjukkan metode sisa harga kontrak sebesar Rp.4.871.000,00 dengan jumlah pembayaran Rp.25.073.000,00 dan angsuran pokok Rp.20.202.000,00. Metode long end interest sebesar Rp.2.656.908,93 dengan jumlah pembayaran Rp.22.858,908,93 dan angsuran pokok Rp.20.202.000,00. Metode short end interest sebesar Rp.2.656.908,93 dengan jumlah pembayaran Rp.22.858,908,93 dan angsuran pokok Rp.20.202.000,00. Metode anuitas sebesar Rp.2.760.420,16 dengan jumlah pembayaran Rp.22.962.423,29 dan angsuran pokok Rp.20.202.003,16. Dari keempat metode tersebut, metode sisa harga kontrak yang menghasilkan pendapatan bunga paling besar, karena bunga yang diperoleh perbulannya tetap atau sama. Sedangkan metode long end interest dan metode short end interest menghasilkan pendapatan yang sama dan paling kecil. Metode anuitas menghasilkan pendapatan bunga yang berada dibawah metode sisa harga kontrak dan diatas metode long end interest dan metode short end interest.
\end{abstract}

Kata Kunci: Metode Sisa Harga Kontrak, Metode Long End Interest, Short End Interest, dan Metode Annuitas, Penjualan Angsuran.

\section{PENDAHULUAN}

Perekonomian Indonesia saat ini mulai beranjak naik semenjak terjadinya krisis moneter di tahun 1998 yang memberikan dampak negatif terhadap semua aspek. Seiring dengan perkembangan perekonomian tersebut, tercipta persaingan di dunia usaha yang semakin ketat antar perusahaan.

Perusahaan didirikan untuk menyediakan barang dan jasa yang dibutuhkan oleh masyarakat. Salah satu tujuan perusahaan jasa maupun dagang yaitu untuk mendapatkan volume penjualan yang menguntungkan dalam jangka panjang dengan tingkat keuntungan yang bisa menjaga kelangsungan hidup perusahaannya. Bagi perusahaan yang kegiatannya menjual barang, tingkat pendapatannya sangat dipengaruhi oleh volume penjualan. Secara langsung pendapatan akan diterima bila penjualan dilakukan secara tunai atau kas dan secara tidak langsung pendapatan akan diterima bila penjualan dilakukan secara kredit atau angsuran.

Istilah penjualan angsuran sendiri digunakan akuntan untuk menyebut jenis penjualan yang pembayarannya dilakukan dengan angsuran periodik selama jangka 
waktu tertentu. Untuk melindungi kepentingan penjual dari kemungkinan tidak ditepatinya kewajiban-kewajiban yang harus ditepati oleh pembeli maka dibuat perjanjian atau kontrak penjualan angsuran sesudah transaksi dilakukan.

Pada umumnya perkembangan penjualan angsuran lebih diminati oleh masyarakat, khususnya penjualan atas barang dengan nominal yang tinggi. Hal ini dikarenakan ketidakmampuan calon pelanggan untuk membayar tunai dan penjualan angsuran dinilai lebih menguntungkan. Dengan adanya penjualan angsuran maka masyarakat dapat memiliki barang yang diinginkan tanpa harus menyediakan uang yang bernilai cukup tinggi, tetapi cukup dengan membayar uang muka (down payment) Terlebih dahulu jika hendak akan membeli secara angsuran, maka konsumen dikenakan beban bunga. Namun biasanya bunga tersebut dibayar bersama-sama dengan pembayaran angsuran.

Berdasakan latar belakang diatas, maka rumusan masalah dalam penelitian ini adalah bagaimana perhitungan bunga penjualan angsuran dengan metodesisa harga kontrak, metodelong end interest, metodeshort end interest, dan metode anuitas serta bagaimana perbedaan perhitungan metode bunga penjualan angsuran dengan metode sisa harga kontrak, metodelong end interest, metodeshort end interest, dan metodeanuitas.

Sedangkan, tujuan penelitian dalam jurnal ini dalahuntuk mengetahui perhitungan bunga penjualan angsuran dengan metode sisa harga kontrak, metodelong end interest, metodeshort end interest, dan metodeanuitas serta untuk mengetahui perbedaan perhitungan metode bunga penjualan angsuran dengan metode sisa harga kontrak, metodelong end interest, metodeshort end interest, dan metodeanuitas.

Menurut Hadori Yunus dan Harnanto (2009: 109) menyatakan penjualan angsuran adalah penjualan yang dilakukan dengan perjanjian dimana pembayarannya dilaksanakan secara bertahap,yaitu pada saat barang- barang diserahkan kepada pembeli, penjual menerima pembayaran pertama sebagian dari harga penjualan (diberikan down payment) dan sisanya dibayar dalam beberapa kali angsuran.

Menurut L. Suparwoto (2009: 167) menyatakan penjualan angsuran adalah penjualan yang pembayarannya dilakukan secara bertahap, di masa yang akan datang dengan tujuan mendapatkan laba.

Menurut Pahala Nainggolan (2007: 137), menyatakan penjualan Angsuran adalah penjualan yang dilakukan secara bertahap dengan perjanjian bahwa aktiva yang dijual akan dibayar secara angsuran atau dengan cara mencicil selama periode yang ditentukan.

Menurut Utoyo Widayat dan Sugito Wibowo (2006: 70), menyatakan penjualan angsuran adalah penjualan barang yang dilaksanakan dengan perjanjian dimana pembayaran dilakukan secara bertahap atau berangsur. 
Menurut F. Zebua (2009: 71), menyatakan penjualan angsuran adaalah penyerahan produk milik penjual kepada pembeli dengan menerima pembayaran uang muka dan sisanya diangsur sesuai yang diperjanjikan.

\section{METODE PENELITIAN}

Penelitian ini merupakan studi kasus yang dilakukan pada Honda Cengkareng. Perusahaan beralamat di Jl. Lingkar Luar Barat No. 12A Cengkareng Barat - Jakarta 11730. Waktu penelian pada tanggal 17 s/d 23 Oktober 2019.

Penelitian ini dilaksanakan dengan menggunakan pendekatan kuantitatif.

Data yang digunakan adalah data sekunder.Data sekunder diperoleh dari situs web dari instansi yang terkait dengan penelitian ini.

Untuk memperoleh data dalam penelitian ini digunakan teknik dokumentasi. Teknik dokumentasi merupakan teknik pengumpulan data yang diperoleh dari perusahaan yang sudah diolah sebelumnya dan data diperoleh dari situs web dari instansi yang berkaitan. Data yang digunakan dalam penelitian ini adalah Harga Motor Honda Vario 125 CBS OTR Jakrta per 20 Oktober 2019.

Dalam mencapai tujuan penelitian yang telah ditetapkan oleh penulis, alat analisis yang digunakan dalam penelitian ini adalahsebagai berikut:

1. Metode sisa harga kontrak

Rumus bunga per periode :

Pokok Angsuran = Harga Jual - DP

Bunga/tahun $=\mathrm{i} \times$ Pokok Angsuran

Bunga /Bulan $=\frac{i \text { idalam } 1 \text { tahun ) }}{\text { fimiah Angsuran }}$

2. Metode bunga jangka panjang (Long End Interest)

Bunga per periode $=\mathrm{i} \times \frac{a}{n} \times$ Ps

3. Metode bunga jangka pendek (Short End Interest)

Bunga per periode $=\mathrm{i} \times \frac{A s}{n} \times \mathrm{P}$

4. Metode Annuitas

\begin{tabular}{|c|} 
Anuitas $=\frac{1-(1 /(1+\mathrm{i}) \mathrm{n}}{\mathrm{i}}$ \\
Jlh Pembayaran Angsuran $=\frac{\text { sisa inargaknontrah }}{\text { faktor anuitas }}$ \\
\hline
\end{tabular}




\section{TEMUAN DAN PEMBAHASAN}

\section{Data Perusahaan}

Tabel 1. Jenis dan Harga Motor Honda Cengkareng

\begin{tabular}{|c|c|c|c|}
\hline Type & $\begin{array}{c}\text { Harga Jual } \\
\text { (Rp) }\end{array}$ & $\begin{array}{c}\text { Uang } \\
\text { Muka } \\
\text { (Rp) }\end{array}$ & $\begin{array}{c}\text { Tenor } \\
\text { (Kali) }\end{array}$ \\
\hline $\begin{array}{c}\text { NEW } \\
\text { VARIO }\end{array}$ & 20.202 .000 .000 & 1.500 .000 & 11 \\
$\begin{array}{c}125 \text { CBS, } \\
\text { OTR JKT }\end{array}$ & & & \\
\hline
\end{tabular}

Sumber: Data Sekunder diolah penulis

\section{Perhitungan Bunga}

$\mathrm{i}=\frac{((\mathrm{Pxt})+\mathrm{DP})-\text { Harga [ua] }}{\text { Harga jual }-D P} \times 100 \%$

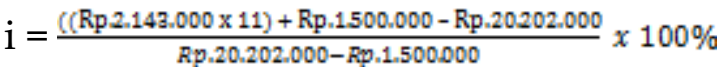

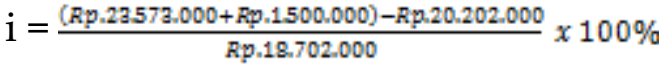

$\mathrm{i}=\frac{\text { Rp.4.971.000 }}{\text { Rp.18.702.000 }} \times 100 \%$

$\mathrm{i}=26,0453427 \%$

Tingkat bunga per tahun adalah $26,0453427 \%$

\section{Metode Sisa Hasil Kontrak}

Pada metode sisa harga kontrak bunga selama masa pembayaran angsuran dihitung dari harga kontrak awal setelah diperhitungkan dengan uang muka, maka dari itu setiap bulan angsuran yang di keluarkan bersifat sama sampai pembayaran angsuran terakhir.

Tabel 2. Perhitungan Bunga Penjualan Angsuran Metode Sisa Harga Kontrak

\begin{tabular}{|c|r|r|r|r|}
\hline $\begin{array}{c}\text { Bulan } \\
\text { Angsuran }\end{array}$ & $\begin{array}{c}\text { Bunga yang } \\
\text { Diperhitungkan } \\
\text { atas Harga } \\
\text { Kontrak (Rp) }\end{array}$ & $\begin{array}{c}\text { Angsuran } \\
\text { atas Harga } \\
\text { Kontrak } \\
\text { (Rp) }\end{array}$ & $\begin{array}{c}\text { Jumlah } \\
\text { Pembayaran } \\
\text { (Rp) }\end{array}$ & $\begin{array}{c}\text { Sisa Harga } \\
\text { Kontrak } \\
\text { (Rp) }\end{array}$ \\
\hline n-0 & & & & $20.202 .000,00$ \\
\hline $\mathrm{n}-0$ & & $1.500 .000,00$ & $1.500 .000,00$ & $18.702 .000,00$ \\
\hline $\mathrm{n}-1$ & $* 442.818,18$ & $1.700 .181,82$ & $2.143 .000,00$ & $17.001 .818,20$ \\
\hline $\mathrm{n}-2$ & $442.818,18$ & $1.700 .181,82$ & $2.143 .000,00$ & $15.301 .636,36$ \\
\hline $\mathrm{n}-3$ & $442.818,18$ & $1.700 .181,82$ & $2.143 .000,00$ & $13.601 .454,54$ \\
\hline $\mathrm{n}-4$ & $442.818,18$ & $1.700 .181,82$ & $2.143 .000,00$ & $11.901 .272,72$ \\
\hline $\mathrm{n}-5$ & $442.818,18$ & $1.700 .181,82$ & $2.143 .000,00$ & $10.201 .090,90$ \\
\hline $\mathrm{n}-6$ & $442.818,18$ & $1.700 .181,82$ & $2.143 .000,00$ & $8.500 .909,08$ \\
\hline $\mathrm{n}-7$ & $442.818,18$ & $1.700 .181,82$ & $2.143 .000,00$ & $6.800 .727,26$ \\
\hline $\mathrm{n}-8$ & $442.818,18$ & $1.700 .181,82$ & $2.143 .000,00$ & $5.100 .545,44$ \\
\hline $\mathrm{n}-9$ & $442.818,18$ & $1.700 .181,82$ & $2.143 .000,00$ & $3.400 .363,62$ \\
\hline $\mathrm{n}-10$ & $442.818,18$ & $1.700 .181,82$ & $2.143 .000,00$ & $1.700 .181,80$ \\
\hline $\mathrm{n}-11$ & $442.818,18$ & $1.700 .181,82$ & $2.143 .000,00$ & 0,00 \\
\hline Jumlah & $\mathbf{4 . 8 7 1 . 0 0 0 , 0 0}$ & $\mathbf{2 0 . 2 0 2 . 0 0 0 , 0 0}$ & $\mathbf{2 5 . 0 7 3 . 0 0 0 , 0 0}$ & \\
\hline
\end{tabular}




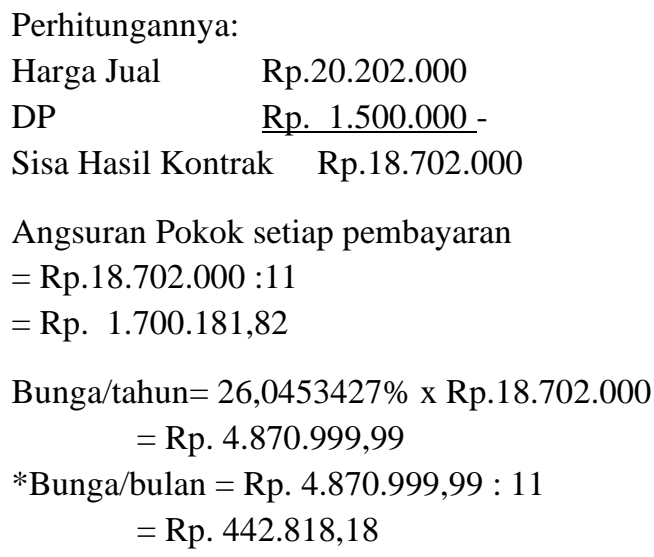

\section{Metode Long End Interest}

Beban bunga diperhitungkan berdasarkan jangka waktu yang sama untuk setiap angsuran, akan tetapi sebagai titik tolak perhitungan bunga dipakai saldo harga kontrak pada setiap awal periode angsuran yang bersangkutan sehingga jumlahnya akan semakin berkurang dari angsuran yang satu dengan angsuran berikutnya.

Tabel 3. Perhitungan Bunga Penjualan Angsuran Metode Long End Interest

\begin{tabular}{|c|r|r|r|r|}
\hline $\begin{array}{c}\text { Bulan } \\
\text { Angsuran }\end{array}$ & $\begin{array}{c}\text { Bunga yang } \\
\text { Diperhitungkan } \\
\text { atas Harga } \\
\text { Kontrak (Rp) }\end{array}$ & $\begin{array}{c}\text { Angsuran } \\
\text { atas Harga } \\
\text { Kontrak } \\
\text { (Rp) }\end{array}$ & $\begin{array}{c}\text { Jumlah } \\
\text { Pembayaran } \\
\text { (Rp) }\end{array}$ & $\begin{array}{c}\text { Sisa Harga } \\
\text { Kontrak } \\
\text { (Rp) }\end{array}$ \\
\hline n-0 & & & & $20.202 .000,00$ \\
\hline n-0 & & $1.500 .000,00$ & $1.500 .000,00$ & $18.702 .000,00$ \\
\hline $\mathrm{n}-1$ & $* 442.818,18$ & $1.700 .181,82$ & $2.143 .000,00$ & $17.001 .818,20$ \\
\hline $\mathrm{n}-2$ & $402.561,98$ & $1.700 .181,82$ & $2.102 .743,80$ & $15.301 .636,36$ \\
\hline $\mathrm{n}-3$ & $362.305,79$ & $1.700 .181,82$ & $2.062 .487,61$ & $13.601 .454,54$ \\
\hline $\mathrm{n}-4$ & $322.049,59$ & $1.700 .181,82$ & $2.022 .231,41$ & $11.901 .272,72$ \\
\hline $\mathrm{n}-5$ & $281.793,22$ & $1.700 .181,82$ & $1.981 .975,04$ & $10.201 .090,90$ \\
\hline $\mathrm{n}-6$ & $241.537,19$ & $1.700 .181,82$ & $1.941 .719,01$ & $8.500 .909,08$ \\
\hline $\mathrm{n}-7$ & $201.280,99$ & $1.700 .181,82$ & $1.901 .462,81$ & $6.800 .727,26$ \\
\hline $\mathrm{n}-8$ & $161.024,79$ & $1.700 .181,82$ & $1.861 .206,61$ & $5.100 .545,44$ \\
\hline $\mathrm{n}-9$ & $120.768,60$ & $1.700 .181,82$ & $1.820 .950,42$ & $3.400 .363,62$ \\
\hline $\mathrm{n}-10$ & $80.512,40$ & $1.700 .181,82$ & $1.780 .694,22$ & $1.700 .181,80$ \\
\hline $\mathrm{n}-11$ & $* * 40.256,20$ & $1.700 .181,82$ & $1.740 .438,02$ & \\
\hline Jumlah & $\mathbf{2 . 6 5 6 . 9 0 8 , 9 3}$ & $\mathbf{2 0 . 2 0 2 . 0 0 0 , 0 0}$ & $\mathbf{2 2 . 8 5 8 . 9 0 8 , 9 3}$ & \\
\hline & & & & \\
\hline
\end{tabular}

$$
\begin{aligned}
& \text { Bunga angsuran: i } x \frac{a}{n} \times \text { Ps } \\
& \begin{aligned}
* n-1 \quad= & 26,0453427 \% \times \frac{1}{11} \times \text { Rp. } 18.702 .000 \\
& =\text { Rp. } 442.818,18 \\
* * n-11 & =26,0453427 \% \times \frac{1}{11} \times \text { Rp. } 1.700 .181,8 \\
= & \text { Rn. } \quad 40.256 .20
\end{aligned}
\end{aligned}
$$

\section{Metode Short End Interest}

Pada metode ini bunga diperhitungkan dari besarnya angsuran yang tetap jumlahnya, sedangkan jangka waktunya selalu dihitung dari permulaan ditandatangani atau berlakunya perjanjian sampai dengan saat pembayaran angsuran yang bersangkutan. 
Tabel 4. Perhitungan Bunga Penjualan Angsuran Metode Short End Interest

\begin{tabular}{|c|r|r|r|r|}
\hline $\begin{array}{c}\text { Bulan } \\
\text { Angsuran }\end{array}$ & $\begin{array}{c}\text { Bunga yang } \\
\text { Diperhitungkan } \\
\text { atas Harga } \\
\text { Kontrak (Rp) }\end{array}$ & $\begin{array}{c}\text { Angsuran } \\
\text { atas Harga } \\
\text { Kontrak } \\
\text { (Rp) }\end{array}$ & $\begin{array}{c}\text { Jumlah } \\
\text { Pembayaran } \\
\text { (Rp) }\end{array}$ & $\begin{array}{c}\text { Sisa Harga } \\
\text { Kontrak } \\
\text { (Rp) }\end{array}$ \\
\hline n-0 & & & & $20.202 .000,00$ \\
\hline n-0 & & $1.500 .000,00$ & $1.500 .000,00$ & $18.702 .000,00$ \\
\hline n-1 & $* 40.256,20$ & $1.700 .181,82$ & $1.740 .438,02$ & $17.001 .818,20$ \\
\hline n-2 & $80.512,40$ & $1.700 .181,82$ & $1.780 .694,22$ & $15.301 .636,36$ \\
\hline n-3 & $120.768,60$ & $1.700 .181,82$ & $1.820 .950,42$ & $13.601 .454,54$ \\
\hline n-4 & $161.024,79$ & $1.700 .181,82$ & $1.861 .206,61$ & $11.901 .272,72$ \\
\hline n-5 & $201.280,99$ & $1.700 .181,82$ & $1.901 .462,81$ & $10.201 .090,90$ \\
\hline n-6 & $241.537,19$ & $1.700 .181,82$ & $1.941 .719,01$ & $8.500 .909,08$ \\
\hline n-7 & $281.793,22$ & $1.700 .181,82$ & $1.981 .975,04$ & $6.800 .727,26$ \\
\hline n-8 & $322.049,59$ & $1.700 .181,82$ & $2.022 .231,41$ & $5.100 .545,44$ \\
\hline n-9 & $362.305,79$ & $1.700 .181,82$ & $2.062 .487,61$ & $3.400 .363,62$ \\
\hline n-10 & $402.561,98$ & $1.700 .181,82$ & $2.102 .743,80$ & $1.700 .181,80$ \\
\hline n-11 & $* * 442.818,18$ & $1.700 .181,82$ & $2.143 .000,00$ & \\
\hline Jumlah & $\mathbf{2 . 6 5 6 . 9 0 8 , 9 3}$ & $\mathbf{2 0 . 2 0 2 . 0 0 0 , 0 0}$ & $\mathbf{2 2 . 8 5 8 . 9 0 8 , 9 3}$ & \\
\hline & & & & \\
\hline
\end{tabular}

$$
\begin{aligned}
& \text { Bunga angsuran: } \mathrm{i} \times \frac{A g}{n} \times \mathrm{P} \\
& \begin{aligned}
* \mathrm{n}-1 \quad=26,0453427 \% \times \frac{1}{11} \times \mathrm{Rp} \cdot 1 \cdot 700 \cdot 181,82 \\
=
\end{aligned} \\
& \begin{aligned}
* * \mathrm{n}-11 & =26,0453427 \% \times \frac{11}{11} \times \mathrm{Rp} \cdot 1 \cdot 700 \cdot 181,82
\end{aligned} \\
& =\text { Rp. } 442.818,18
\end{aligned}
$$

\section{Metode Anuitas}

Pada metode anuitas jumlah pembayaran angsuran setiap periode sama besarnya, dan di dalam setiap pembayaran angsuran mengandung unsur pembayaran pokok pinjaman dan bunga angsuran.

Tabel 5. Perhitungan Bunga Penjualan Angsuran Metode Anuitas

\begin{tabular}{|c|r|r|r|r|}
\hline $\begin{array}{c}\text { Bulan } \\
\text { Angsuran }\end{array}$ & $\begin{array}{c}\text { Pembayaran } \\
\text { Menurut } \\
\text { Anuitas (Rp) }\end{array}$ & $\begin{array}{c}\text { Bunga } \\
(\mathbf{R p})\end{array}$ & $\begin{array}{c}\text { Jumlah } \\
\text { Pembayaran } \\
\text { (Rp) }\end{array}$ & $\begin{array}{c}\text { Sisa Harga } \\
\text { Kontrak } \\
\text { (Rp) }\end{array}$ \\
\hline $\mathrm{n}-0$ & & & & $20.202 .000,00$ \\
\hline $\mathrm{n}-0$ & $1.500 .000,00$ & & $1.500 .000,00$ & $18.702 .000,00$ \\
\hline $\mathrm{n}-1$ & $1.951 .129,39$ & $* 442.818,18$ & $1.508 .311,21$ & $17.193 .688,79$ \\
\hline $\mathrm{n}-2$ & $1.951 .129,39$ & $407.105,02$ & $1.544 .024,37$ & $15.649 .664,42$ \\
\hline $\mathrm{n}-3$ & $1.951 .129,39$ & $370.546,25$ & $1.580 .583,14$ & $14.069 .081,28$ \\
\hline $\mathrm{n}-4$ & $1.951 .129,39$ & $333.121,86$ & $1.618 .007,53$ & $12.451 .073,75$ \\
\hline $\mathrm{n}-5$ & $1.951 .129,39$ & $294.811,35$ & $1.656 .318,04$ & $10.794 .755,71$ \\
\hline $\mathrm{n}-6$ & $1.951 .129,39$ & $255.593,74$ & $1.695 .535,65$ & $9.099 .220,06$ \\
\hline $\mathrm{n}-7$ & $1.951 .129,39$ & $215.447,55$ & $1.735 .681,84$ & $7.363 .538,22$ \\
\hline $\mathrm{n}-8$ & $1.951 .129,39$ & $174.350,80$ & $1.776 .778,59$ & $5.586 .759,63$ \\
\hline $\mathrm{n}-9$ & $1.951 .129,39$ & $132.280,97$ & $1.818 .848,42$ & $3.767 .911,21$ \\
\hline $\mathrm{n}-10$ & $1.951 .129,39$ & $89.215,04$ & $1.861 .914,35$ & $1.905 .996,86$ \\
\hline $\mathrm{n}-11$ & $1.951 .129,39$ & $* * 45.129,40$ & $1.905 .999,99$ & \\
\hline Jumlah & $22.962 .423,29$ & $2.760 .420,16$ & $20.202 .003,13$ & \\
\hline
\end{tabular}




$$
\begin{aligned}
& \text { Perhitungannya: } \\
& \text { Anuitas }=\frac{1-\frac{1}{(1+i)^{n}}}{i} \\
& =\frac{1-\frac{1}{(1+0,0236775943)^{11}}}{0,0236775843} \\
& =9,5852177 \\
& \text { Dengan, } \mathrm{i}=26,0453427: 11 \\
& =0.0236775843 \\
& \mathrm{Jlh} \text { pembayaran angsuran }=\frac{\text { SHK }}{\text { Amuitas }} \\
& =\frac{R p \cdot 18.702 .000}{9,5852177} \\
& =\mathrm{Rp} \cdot 1 \cdot 951 \cdot 129,39 \\
& * \mathrm{n}-1=26,0453427 \% \times \frac{1}{11} \times \text { Rp. } 18.702 .000 \\
& =\text { Rp. } 442.818,18 \\
& * * \mathrm{n}-11=26,0453427 \% \text { x } \frac{1}{11} \text { x Rp. } 1.905 .996,86 \\
& =\text { Rp. 45.129,40 }
\end{aligned}
$$

Tabel 6. Rekapitulasi Perhitungan Bunga Penjualan Angsuran Honda Cengkareng

\begin{tabular}{|l|c|c|c|}
\hline Keterangan & $\begin{array}{c}\text { Angsuran } \\
\text { Pokok (Rp) }\end{array}$ & $\begin{array}{c}\text { Pendapatan } \\
\text { Bunga (Rp) }\end{array}$ & $\begin{array}{c}\text { Jumlah } \\
\text { Pembayaran } \\
\text { (Rp) }\end{array}$ \\
\hline $\begin{array}{l}\text { Metode } \\
\text { Sisa Harga } \\
\text { Kontrak }\end{array}$ & $20.202 .000,00$ & $4.871 .000,00$ & $25.073 .000,00$ \\
\hline $\begin{array}{l}\text { Metode } \\
\text { Long End } \\
\text { Interest }\end{array}$ & $20.202 .000,00$ & $2.656 .908,93$ & $22.858 .908,93$ \\
\hline $\begin{array}{l}\text { Metode } \\
\text { Short End } \\
\text { Interest }\end{array}$ & $20.202 .000,00$ & $2.656 .908,93$ & $22.858 .908,93$ \\
\hline $\begin{array}{l}\text { Metode } \\
\text { Anuitas }\end{array}$ & $20.202 .003,13$ & $2.760 .420,16$ & $22.962 .423,29$ \\
\hline
\end{tabular}

Berdasarkan tabel 6 perhitungan bunga menggunakan metode sisa harga kontrak sebesar Rp.4.871.000,00 dengan jumlah pembayaran Rp.25.073.000,00 dan angsuran pokok Rp.20.202.000,00. Metode long end interest sebesar Rp.2.656.908,93 dengan jumlah pembayaran Rp.22.858,908,93 dan angsuran pokok Rp.20.202.000,00. Metode short end interest sebesar Rp.2.656.908,93 dengan jumlah pembayaran Rp.22.858,908,93 dan angsuran pokok Rp.20.202.000,00. Metode anuitas sebesar Rp.2.760.420,16 dengan jumlah pembayaran Rp.22.962.423,29 dan angsuran pokok Rp.20.202.003,13.

Dari keempat metode tersebut, metode sisa harga kontrak yang menghasilkan pendapatan bunga paling besar, karena bunga yang diperoleh perbulannya tetap 
atau sama. Sedangkan metode long end interest dan metode short end interest menghasilkan pendapatan yang sama dan paling kecil, karena bunga perbulannya berbeda. Metode anuitas menghasilkan pendapatan bunga yang berada dibawah metode sisa harga kontrak dan diatas metode long end interest dan metode short end interest. Sama halnya dengan metode long end interest dan metode short end interest, bunga yang dihasilkan metode anuitas berbeda-beda setiap bulannya.Metode yang paling tepat digunakan perusahaan dalam melakukan penjualan angsuran adalah metode sisa harga kontrak. Karena metode ini menghasilkan pendapatan bunga paling besar.

\section{KESIMPULAN DAN SARAN}

\section{Kesimpulan}

Berdasarkan hasil analisis dan pembahasan dapat disimpulkan bahwa:

1. Metode sisa harga kontrak mengasilkan bunga sebesar Rp.4.871.000,00 dengan jumlah pembayaran Rp.25.073.000,00.

2. Metode long end interest menghasilkan bungasebesar Rp.2.656.908,93 dengan jumlah pembayaran Rp.22.858,908,93

3. Metode short end interest menghasilkan bunga sebesar Rp.2.656.908,93 dengan jumlah pembayaran Rp.22.858,908,93

4. Metode anuitas menghasilkan bungasebesar Rp.2.760.420,16 dengan jumlah pembayaran Rp.22.962.423,29.

5. Metode sisa harga kontrak yang menghasilkan pendapatan bunga paling besar, karena bunga yang diperoleh perbulannya tetap atau sama. Sedangkan metode long end interest dan metode short end interest menghasilkan pendapatan yang sama dan paling kecil

\section{Saran}

Sebaiknya Honda Cengkareng tetap menggunakan metode sisa harga kontrak untuk menghitung besarnya bunga dalam penjualan angsurannya dan Honda Cengkareng diharapkan dapat meningkatkan jumlah penjualannya, karena semakin banyak produk yang terjual, maka semakin besar pula laba yang didapatkan oleh perusahaan.

\section{DAFTAR PUSTAKA}

Http://www.hondacengkareng.com, diakses tanggal 17 Oktober 2019

Irmayanti, Elis dan M. Anas. 2018. Analisis Penjualan Angsuran Dalam Menentukan Tingkat Suku Bunga Dan Uang Muka Penjualan Untuk Menentukan Laba Pada PT.

Putra Rinjani III Kertosono. Jurnal Ekonomi, Vol. 02 No. 03. Universitas 
Nusantara Kediri. (http://simki.unpkediri.ac.id, diunduh tanggal 17 Oktober 2019)

Nainggolan, Pahala. 2007. Akuntansi Keuangan Yayasan Dan Lembaga Nirlaba Sejenis. Jakarta: PT. Raja Grafindo Persada

Prabowo, P. A. (2020). ANALISA PERILAKU KONSUMEN JASA KATERING UNTUK KEPERLUAN PESTA DI SURABAYA. JURNAL EKBIS: ANALISIS, PREDIKSI DAN INFORMASI, 21(1), 69-90.

Riyanto, Bambang. 2008. Dasar-dasar Pembelanjaan Perusahaan. Yogyakarta: Penerbit GPFE.

Sari, Herlina. 2013. Analisis Metode Perhitungan Bunga Penjualan Angsuran pada PT. Adira Dinamika Multi Finance Tbk. Jurnal Akuntansi. Universitas Gunadarma. (http://herlinasarieb13.blogspot.com, diunduh 17 Oktober 2019)

Suparwoto, L. 2004. Akuntansi Keuangan Lanjutan. Yogyakarta: BPFE.

Syarif, M. Ryan. 2015. Analisis Metode Perbandingan Perhitungan Bunga Penjualan Angsuran Pada PT. Toyota Astra Financial Service. Jurnal Akuntansi Internasional. Universitas

Gunadarma.(http://ryansyarifvidiaksana.blogspot.com, diunduh 17 Oktober 2019)

Syairozi, M. (2015). Pengaruh Faktor Eksternal (Inflasi, Bunga) Dan Faktor Internal (Bagi Hasil, Jumlah Bank) Terhadap Deposito Mudharabah Pada Perbankan Syariah Di Indonesia (Doctoral dissertation, Universitas Brawijaya).

Syairozi, M. I., \& Susanti, I. (2018). Analisis Jumlah Pengangguran dan Ketenagakerjaan terhadap Keberadaan Usaha Mikro Kecil dan Menengah di Kabupaten Pasuruan. Jurnal Samudra Ekonomi dan Bisnis, 9(2), 198-208.

Widiastoeti, H., \& Sari, C. A. E. (2020). PENERAPAN LAPORAN KEUANGAN BERBASIS SAKEMKM TERHADAP KUALITAS LAPORAN KEUANGAN PADA UMKM KAMPUNG KUE DI RUNGKUT SURABAYA. JURNAL EKBIS: ANALISIS, PREDIKSI DAN INFORMASI, 21(1), 1-15.

Widayat, Utoyo dan Sugito Wibowo. 2006. Akuntansi Penjualan Angsuran dan 